\title{
Teologia, Ciêneia e Cultura: diálogo necessário e inadiável
}

Recebido: 27/01/2017. Aprovado: 31/07/2017.

\section{Fernando Cardoso Bertoldo*}

Resumo: O artigo apresenta aspectos referentes ao diálogo da teologia com as ciências e a cultura do povo, e também trata da recepção da linguagem teológica pelo crente. Pode-se falar não só da possibilidade de diálogo entre teologia e ciência e cultura do povo, mas também da necessidade inadiável desse diálogo, especialmente no contexto contemporâneo, onde a teologia é tantas vezes menosprezada no ambiente público. Tendo em vista essa mudança de época e frente às exigências da sociedade contemporânea, é preciso zelar mais pela qualidade da formação intelectual. Isso tudo para uma maior qualificação e competência dos seminaristas e sacerdotes, futuros teólogos, como serviço a Deus e a seu povo, partindo do pressuposto de que existe um sensivel impacto das descobertas científicas na recepção da teologia pelo crente.

Palavras-chave: Teologia. Ciência. Cultura. Teólogo. Crente.

Abstract: The paper presents aspects concerning the theology of dialogue with the sciences and the culture of the people, and also shows how is the reception of theological language by the believer. One can speak not only of the possibility of dialogue between theology and science and culture of the people but also the urgent need of this dialogue, especially in the contemporary context, where the theology is so often overlooked in the public environment. In view of this change of era and facing the demands of contemporary society, we must ensure more by the quality of intellectual formation. All this for a higher qualification and competence of seminarians and priests, theologians future, as service to God and his people, assuming that there is a significant impact of scientific discoveries in receipt of theology by the believer.

Keywords: Theology. Science. Culture. Theologian. Believer.

* Doutorando em Teologia pela EST, São Leopoldo, RS. Mestre em Teologia (2017) pela PUCRS, Porto Alegre. Bacharel em Psicologia (2013) pela PUCRS. Bolsista da CAPES.

E-mail: nandobertoldo@hotmail.com 


\section{Introdução}

Dos tempos do Concílio Vaticano I (1869-1870) aos do Concílio Vaticano II (1962-1965), a comunidade científica desenvolveu e mudou substancialmente a paisagem contextual à sua volta, e no tempo do pós Vaticano II houve mais mudanças relevantes na cosmovisão de mundo, com o avanço da ciência e tecnologia principalmente no campo da medicina, da comunicação e informatização globalizadas. O Vaticano I, porque tinha diante de si o Racionalismo, discutiu a relação entre fé e razão, mas foi a proposta do Vaticano II, iniciado por João XXIII, que procurou fazer a devida atualização e abrir as portas da Igreja e da teologia para o diálogo com a cultura e ciência modernas, com as diferentes confissões religiosas, bem como a renovação na estrutura interna da Igreja.

\section{Da oposição cega ao diálogo generativo}

A conscientização, por parte da Igreja, acerca do distanciamento das culturas gerou vários movimentos pastorais, de modo especial na América Latina. ${ }^{1}$ A tentativa de dialogar com a ciência exigiu dos teólogos a internalização de novos conceitos, uma vez que a ciência é um campo que, para dialogar requer competência, sem levar em conta gênero, raça, crença ou nacionalidade. A capacidade racional se torna, então, a condição de possibilidade desse diálogo.

Com a globalização da economia, da comunicação e informação surgem também novos desafios para a teologia, a necessidade de articular o diálogo em vista de uma paz mundial, e, na iminente destruição do planeta, a sobrevivência da humanidade, dentro de um contexto em que o pluralismo cultural, religioso, ideológico e científico aponta para novas realidades em que a teologia se tornou só mais uma voz em meio a outras vozes, sem qualquer hegemonia.

A teologia reconhece este clima cultural da pós-modernidade, mediante a filosofia e a literatura, e responde a este desafio com um processo de purificação dos seus conhecimentos, argumenta sobre as verdades do cristianismo em meio à pluralidade de culturas e religiões sem dogmatismo, uma tentativa de ressignificar o cristianismo nos vários contextos. ${ }^{2}$

\footnotetext{
Cf. ZILLES, Urbano. História da Teologia Cristã, p. 136.

2 Cf. GIBELLINI, Rosino. A Teologia do Século XX, p. 583.
} 
Poderíamos dizer que as relações dialógicas entre teologia e ciência, e aqui, ciências naturais, nem sempre foram cordiais, pois com a quebra da hegemonia católica no ocidente no século XVI, houve em decorrência deste evento, uma autonomia em relação às investigações no campo científico, independente da Igreja. Somados a constrangimentos históricos devido às tentativas de silenciar cientistas e suas obras, que foram resultados de pesquisas que consequentemente colocariam em certa contradição aspectos da doutrina cristã, que no seu tempo, eram aceitos devido ao alcance limitado dos instrumentos de verificação, dizer que o diálogo começou mal, não é exagero.

Então esta relação entre religião e ciência, mais especificamente entre a teologia cristã e as diversas ciências da natureza, assumiram nesta perspectiva histórica desde o "conflito aberto, à separação, à fusão e ao diálogo"3. Com precariedades poderíamos dizer que a questão heliocêntrico-geocêntrica foi o pivô de uma crise que nos séculos seguintes veio acentuar um abismo entre teologia e ciência. Esta emancipação do saber humano que começou na renascença, Duquoc a descreve bem na principal característica da época, ou seja, que até o período do Iluminismo, houve um detrimento processual das questões teológicas em favor de um pensamento com base na verificação empírica, observada e repetida, mais segura em relação às deduções lógicas puras, com base na razão instrumentalizada por uma metafísica do ser. ${ }^{4}$ Nos séculos XVII e XVIII, a teologia não mediu com interesse este abismo em relação ao seu método usado, com base nas Escrituras, defendidas com fervor, e deixou passar despercebida uma falta grave cometida pela ciência empírica, que foi a indiferença "em relação às formas poéticas e simbólicas de apreensão e de interpretação da experiência humana, feliz ou trágica".

No século XX o diálogo com a ciência ocorre como tentativa de convergir no ser humano os benefícios das ciências em relação à saúde, comodidade e comunicação, apesar dos seus contras, como por exemplo, servir de instrumento político para as mais diversas e terríveis ideologias, que culminaram em experiências nas duas grandes guerras, como também em relação à economia capitalista que aumentou ainda mais a distância entre ricos e pobres. A teologia, além de abarcar o homem todo, a partir

\footnotetext{
SANCHES, Mário Antonio. O diálogo entre teologia e ciências naturais, p. 179.

4 Cf. DUQUOC, Christian. A Teologia no Exílio: o desafio da sobrevivência da teologia na cultura contemporânea.

5 Cf. Ibid., p. 19.
} 
do seu significado para Deus revelado na história, contribuiu também no que trata da ética em relação ao uso das mesmas tecnologias pelo gênero humano.

Podemos dizer que o diálogo entre estas duas áreas do saber deve partir do respeito à diversidade cultural, com características tais como a "valorização da diversidade, abertura à complementaridade, diálogo respeitoso, sem arrogância e sem a pretensão de que uma área se submeta à

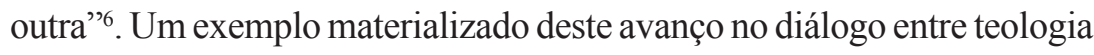
e ciência é o testemunho do Dr. Francis Collins, autor do Best Seller $A$ Linguagem de Deus ${ }^{7}$, onde o renomado diretor do projeto Genoma Humano Internacional, relata o desenvolvimento da sua crença, desde o seu período como ateu, passando ao cético, chegando à crença, justamente porque suas pesquisas relacionadas ao genoma humano mostraram uma inteligência por trás de toda a realidade. Isto, somado ao dom da fé, é um avanço astronômico em relação aos ateus que defendem com unhas e dentes a incompatibilidade entre fé e ciência.

Dr. Collins enfatiza no seu livro que a ciência não exclui Deus da vida, pois assim como a ciência laboratorial investiga o que há de natural como objeto de pesquisa, ou seja, o material, a teologia fornece diversas respostas para questões fundamentais de uma esfera inquietante para o gênero humano, a espiritual. Collins também salienta que a crença espiritual no meio científico é maior do que o senso comum imagina. Em pesquisa realizada em 1917 e 1997 na comunidade científica, o percentual dos que creem numa entidade divina que interage providencialmente com os homens foi em ambas as datas em torno de $40 \%$, o que descreve que o diálogo teológico tem campo fértil com as ciências. ${ }^{8}$

Em relação à cultura do povo e às mudanças ocorridas nestes tempos hodiernos, o debate em relação ao sentido de cultura nos conduz ao entendimento das sociedades altamente modernas, onde juntamente com questões relacionadas a diversos fenômenos como a secularização e a pluralização, assim como a virtualização, esta sinônimo dos tempos atuais, nos faz pensar que a fé, hoje, é mais uma possibilidade frente a outras mundanas e imediatas. Uma surdez à linguagem religiosa que exige transcendentalidade de certo modo é notada, pois há uma sobreposição

\footnotetext{
6 Cf. SANCHES, Mário Antonio. O diálogo entre teologia e ciências naturais, p. 180.

7 Cf. COLLINS, Francis. A Linguagem de Deus.

8 Cf. Ibidem.
} 
do imanente sobre o transcendente, do visível sobre o invisível. Susin, todavia, ajuda a perceber que

as sociedades contemporâneas, entre modernidade e pós-modernidade, num mundo globalizado que atinge também regiões de pré-modernidade, precisam de teologia franca e aberta, teologia que parta de dentro das experiências da fé, e não só de ciências da religião, para dar conta dessa tarefa em relação ao 'bem comum', à convivência social. ${ }^{9}$

O mais importante neste diálogo é que ele seja orientado para o bem e o progresso da sociedade, em todos os aspectos. O objetivo não deve ser a simples defesa da ciência pela ciência através dos cientistas nem o da religião pela religião através dos teólogos, mas, como descreveu Sanches, a promoção do bem-estar coletivo, partindo de uma concepção que "entende como desastrosas e danosas para a sociedade quaisquer uma das seguintes situações: uma ciência que rejeita a religião, ou uma religião que rejeita a ciência"10. Seria possível, então, falarmos de uma ciência da fé?

\section{Ciência da fé?}

Tendo em vista as considerações feitas cabe repensar as origens do diálogo entre teologia e ciência devido ao fato de falar não só da possibilidade de diálogo entre teologia e ciência e cultura do povo, mas também da necessidade desse mesmo diálogo, especialmente no contexto atual, onde a teologia é tantas vezes colocada como que de escanteio no ambiente público, tornando-se algo útil apenas privadamente. Embora a teologia não produza a fé ou a Igreja mesma, ela porém procura entender o que se crê no testemunho de fé da Igreja. Parte-se de uma fé, mas de uma fé que inquieta a pessoa humana na busca de sua mesma compreensão. Encontramos então o princípio da fé à procura da inteligência (fides quaerens intellectum).

Anselmo de Aosta (1033-1109) expõe algo magnífico no final do primeiro capítulo e início do segundo de sua obra Proslogion:

9 SUSIN, Luiz Carlos. O estatuto epistemológico da teologia como ciência da fé e a sua responsabilidade pública no âmbito das ciências e da sociedade pluralista, p. 561.

10 Cf. SANCHES, Mário Antonio. O diálogo entre teologia e ciências naturais, p. 180. 
Não procuro, Senhor, penetrar a tua profundidade, porque de maneira nenhuma lhe comparo a minha inteligência, mas desejo entender, de certa forma, a tua verdade que o meu coração crê e ama. Nem procuro entender para crer, mas creio para entender. Pois, até isto eu creio: que, se não acreditar, não entenderei. Portanto, Senhor, tu que dás o entendimento da fé, concede-me que, quanto sabes ser-me conveniente, entenda que existes como acreditamos e que és o que acreditamos [seres]. ${ }^{11}$

A citação de Anselmo é oportuna porque se hoje ainda ocorrem dúvidas acerca da possibilidade de diálogo entre teologia e ciência e cultura do povo, no século de Anselmo teólogos e dialéticos travavam embates homéricos, mas sempre houve quem mostrasse a possibilidade de conciliação entre elas. Anselmo foi um deles. Vejamos. Na relação entre teólogos e dialéticos, Berengário ${ }^{12}$ era favorável à dialética, fazendo uso das categorias lógicas, pois, na busca da verdade, a razão lhe parecia o melhor guia. Porém, muitos teólogos reagiram, considerando a dialética e as artes liberais desnecessárias: "Pedro Damião, bispo de Ravena, comparava a dialética a uma humilde serva da religião"13, sendo um instrumento de confusão na busca da verdade, visto ser a razão divina superior à razão humana. Lanfranco, mestre de Anselmo, todavia, era mais moderado e procurava um meio-termo, uma espécie de simbiose entre a dialética e a teologia, confirmando, assim, uma ajuda da dialética às compreensões das verdades da fé. Seguindo a posição de Vasconcellos, "mais do que propriamente um conflito, ocorre, sem dúvida, um amplo debate sobre a dialética e sua relação com a fé e a autoridade"14, e An-

11 ANSELMO. Proslogion, cap. I-II. Para um aprofundamento acerca da relação entre fé, razão e verdade em Santo Anselmo indicamos: ROMIO, Jocimar; HACKMANN, Geraldo Luiz Borges. Fé, razão e verdade: a contribuição de Anselmo de Cantuária, p. 47-63.

12 Para Berengário, a razão é superior à autoridade "porque ela conduz à verdade de forma evidente, ou seja, de uma tal forma, que não pode ser negada" (VASCONCELLOS, M. Fides ratio auctoritas: o esforço dialético no 'Monologion' de Anselmo de Aosta: as relações entre fé, razão e autoridade, p. 32). "É sua esta frase característica, citada frequentemente: 'É próprio de um grande coração recorrer sempre à dialética: recorrer a ela é recorrer à razão que nele é a imagem de Deus'. Deixando, pois, de lado as autoridades sagradas, ele estabelecia como axioma que era preciso tudo criticar para tudo compreender" (NÉDONCELLE, M. Existe uma filosofia cristã?, p. 39).

13 Ibid., p. 40. "Pedro Damião atingia em nome da antidialética aos excessos da dialética. Ele chegava mais ou menos ao mesmo resultado que Anselmo de Besate que, ampliando uma observação de Aristóteles, encontrava um meio entre duas proposições contraditórias. Tais adversários uniam-se para negar a possibilidade de uma filosofia cristã: pois privavam a filosofia de toda base" (Ibid., p. 40-41).

14 VASCONCELLOS, M. Fides ratio auctoritas: o esforço dialético no 'Monologion' de Anselmo de Aosta: as relações entre fé, razão e autoridade, p. 15. "Anselmo, de modo mais 
selmo representa esse caminho de busca da compreensão ou explicitação racional da fé. Xavier esclarece:

Por um lado, a fé não é, para Anselmo, uma sede de repouso ou de pacificação interior, mas antes um motivo de inquietação e de procura; é um ponto de partida, não um ponto de chegada. Por outro lado, também a inteligência da fé não é fator de repouso, como se fosse um dado adquirido, mas é realmente apenas um grau superável de compreensão. Deste modo, a busca da inteligência da fé, em Anselmo, significa uma atitude de vigilância crítica, quer da fé, quer da inteligência da fé. A vigilância crítica da fé impede que esta seja crédula ou, então, se transforme em fonte de fanatismo. A vigilância crítica da inteligência da fé, por sua vez, obsta à tentação de qualquer redução racionalista da fé e relativiza as expressões doutrinárias da mesma. ${ }^{15}$

Hoje também devemos utilizar a argumentação racional para fundamentar e compreender os conteúdos revelados da própria fé e da doutrina da Igreja, pois a fé requer a compreensão de seu objeto com a ajuda da razão. A interface com a ciência, como parceira de diálogo, então, é não só útil, mas indispensável. E a teologia, como ciência da fé (glaubenswissenschaft), é um modo qualificado de compreender essa mesma fé e apresentá-la, contra fideísmos, racionalismos, fundamentalismos e outros radicalismos da sociedade hodierna. Sobre essa cientificidade da teologia, no entanto, requer-se um conceito aberto de ciência, que abarque áreas de pesquisa e metodologias diferentes das positivas. Conforme Hammes, "para ser reconhecida como ciência, na sociedade aberta e pluralista, de separação entre Igreja (religião) e Estado, a Teologia precisa dar conta de ao menos quatro condições: estatuto epistemológico próprio, liberdade de pesquisa, inserção científica e relevância pública" ${ }^{16}$.

Especialmente pelos meios de comunicação social, vê-se na sociedade atual certa tendência ao fideísmo. Grupos surgem como que para combater a sadia relação da Igreja com as ciências ou com o mundo da cultura, como se fossem opostos. "Há pessoas e grupos que reagem às mudanças fechando-se ao real mediante práticas fundamentalistas, com rigidez, buscando segurança em um estilo de vida próprio do passado"

maduro e fecundo do que seus contemporâneos, soube evitar posturas reducionistas, mostrando, em meio ao debate sobre o estatuto da dialética, que, bem compreendida, esta não será nem panaceia, nem balbúrdia, mas gáudio" (Ibid., p. 228).

XAVIER, M. L. L. O. O nome anselmiano de Deus, p. 270.

HAMMES, Érico João. Pode teologia ser ciência? p. 549. 
(CNBB, Doc. 93, n. 22). Isso significa que a ideia é de que basta gostar/ amar e se sentir bem com algo, sem a necessidade racional. A sociedade de consumo e a busca do bem-estar ensinam que só vale a pena viver se há o máximo de satisfação e prazer, numa cultura do descartável e do provisório. Ora, a capacidade/possibilidade cognitiva deve procurar aquilo que ama, porque quanto mais ama, mais deseja conhecer, como bem expressa João Paulo II na Encíclica Fides et Ratio (n. 42): “Assim, o desejo da verdade impele a razão a ir sempre mais além, esta fica como que embevecida pela constatação de que a sua capacidade é sempre maior do que aquilo que alcança". Uma fé maior gera um desejo de compreensão mais profundo, seja do próprio Deus, seja de sua revelação. É um erro muito grande a separação entre fé e razão, porque é a própria fé que faz o ser humano desejoso de saber, de conhecimento e intelecção. Seria negligência de sua parte não buscar compreender, já que a razão humana é capaz de iluminar os mistérios da fé cristã e demonstrar sua coerência, sua conveniência e sua necessidade. Dirá acertadamente o Cardeal Walter Kasper: "A fé não é apenas um sentimento vago, difuso ou uma prática costumeira; ela tem um conteúdo concreto, que podemos e devemos conhecer. Só podemos amar o que conhecemos, e o que amamos também queremos conhecer mais profundamente" 17 .

A teologia transita entre a linguagem comum, cotidiana e a linguagem científica condicionada às regras pautadas pela própria comunidade científica, apresentando uma linguagem própria. Para se fazer entender, utiliza-se da simbologia, da arte, da iconografia. Usa a linguagem da fé e quer provocar no ouvinte uma ação à luz da fé, esclarecida pelo teólogo no meio da comunidade de fé. Sua linguagem assume o compromisso com a fé e a Palavra de Deus na comunidade, e se põe a serviço desta prática e não dos interesses da comunidade científica ou de qualquer outra instituição. ${ }^{18}$ Trata-se, então, de uma questão de identidade e confessionalidade: embora seja urgente este diálogo com a ciência e

17 KASPER, Cardeal Walter. Servidores da alegria: existência sacerdotal - serviço sacerdotal, p. 83.

18 Cf. LIBÂNIO, João Batista; MURAD, Afonso. Introdução à Teologia: perfil, enfoques, tarefas, p. 89-90. Sobre a chamada "teologia pública", Susin é veemente quando diz que ela "não é um voo por cima das pertenças e das confissões, pois deixaria de ser teologia. Nem é uma perda de identidade confessional - só se pode elaborar teologia da própria confissão, não de confissão alheia, o que explica os diferentes níveis de pluralismo teológico - mas é abertura responsável e dialogal exatamente num mundo globalizado e não-homogêneo" (SUSIN, Luiz Carlos. O estatuto epistemológico da teologia como ciência da fé e a sua responsabilidade pública no âmbito das ciências e da sociedade pluralista, p. 561). 
cultura atuais, não se pode, em vista do diálogo, abdicar daquilo que é próprio e essência ou fundamento da religião. O diálogo é um valor que não pode suprimir ou ignorar o valor da identidade da fé crida pelo fiel e anunciada pela Igreja.

Santo Tomás de Aquino nos seus escritos afirmou que uma senhora idosa com fé possui de modo mais perfeito o seu objeto, a sua ciência, que um teólogo absorvido nas suas especulações teológicas. Embora a teologia se defina como logos da fé e não como crença ou fé, o teólogo que atua apenas no campo acadêmico e intelectual encontra-se em desvantagem com relação àquele que, além disso, vive sua experiência de fé eclesial. Não é suficiente, então, a explicitação do conteúdo da fé (fides quae) por parte do teólogo, mas requer-se dele também cada vez mais o ato de crer (fides qua), pessoal e comunitariamente.

A linguagem do teólogo é exercida, então, dentro da sua comunidade de fé, assim como a do crente, porém o teólogo deve interpretar esta linguagem que é a expressão da experiência de fé da mesma comunidade a qual pertence, de forma crítica e com método rigoroso. É missão do teólogo atuar como um balizador para que o crente e a cultura não extrapolem a experiência de fé para além do que foi revelado ou que esteja em contraste com a mesma revelação. Aqui encontramos essa dupla tarefa, nem sempre explícita ou fácil de se concretizar: inculturação da fé e evangelização da cultura.

O crente vive a sua fé na alegria da comunicação/relação com o infinito, muitas vezes com certa precariedade intelectual, porém esta não é exigida em princípio, pois a vivência em comunidade supre a carência de entendimento imediato do dado revelado, sendo a fé a legítima vida na relação com o transcendental. Tanto para o teólogo como para o crente, "não basta o discurso sobre Deus, mas é preciso ouvir o que Ele tem para nos dizer" 19 . Não há atividade teológica, como não há crente, sem o pressuposto da fé, que prepara os ouvidos para a mensagem revelada, assim como prepara o homem todo para viver uma vida que foi enxertada na vida natural, uma vida sobrenaturalizada, em comunicação com o infinito e com a Verdade para o gênero humano.

Ambos, como membros de uma realidade maior que é a Igreja, tanto o teólogo como o crente existem a partir deste anúncio de Deus. Não compete à Igreja elaborar teologias, ou seja, definir o que cada

19 ZILLES, Urbano. História da Teologia Cristã, p. 193. 
teólogo deve criticar ou contribuir no seu tempo, mas cabe à Igreja, através do seu Magistério, definir limites para que os teólogos também não extrapolem para além do dado revelado, para não acabarem criando somente uma teologia da especulação pela especulação. Do mesmo modo que o crente possui limites, ele também adere ao conteúdo da fé com a sua razão e obediência dentro da salutar vida comunitária, com seu culto. É radical, mas precioso também, dizer que uma das maravilhas do crente seria obedecer com a fé e o teólogo o compromisso de obedecer criticamente com a fé.

Ao teólogo poderíamos também dizer, mesmo que de modo simplista, que a sua função é atualizar em linguagem a mensagem revelada para o crente a viver na fé. Este viver na fé se dá através da experiência cotidiana. Esta experiência cotidiana sobrenaturalizada pela fé, como resposta a Deus, pode avançar para uma experiência mística, que leva tanto o crente como o teólogo para um comprometimento de uma vida mais íntima com Deus, uma resposta para além do que é comunicável entre os homens, sendo expressa a experiência de modo muito limitado, num linguajar que descreverá apenas precariamente o que não pode ser descrito, mas apenas experimentado e vivido.

Uma característica fundamental existente entre o teólogo e o crente, então, é que ambos em primeiro lugar são ouvintes da Palavra de Deus, e cada qual a acolhe na sua capacidade e na sua vocação vivendo-a conforme solicitado na fé, exercendo a sua função como membros deste Corpo Místico, diverso em seus órgãos, mas com a mesma finalidade, viver em peregrinação para a realidade final que é a visão de Deus. Os sacerdotes, então, são importantes meios de efetivação desse diálogo possível e inadiável entre teologia, ciência e cultura. Sua formação intelectual pode muito contribuir nesta benfazeja missão.

\section{A formação intelectual como dimensão da formação sacerdotal}

Se o programa fides quaerens intellectum visa à atualização da linguagem da fé para dentro da cultura e da visão de mundo, a questão que se nos coloca atualmente é se falta-nos competência para fazer tal atualização para o mundo de hoje. "O fenômeno da subjetivação da fé faz com que não só um crescente número de cristãos, mas também os seminaristas, manifestem menor sensibilidade ao conjunto global e obje- 
tivo da doutrina da fé. Preferem uma adesão subjetiva ao que agrada, ao que corresponde à própria experiência" ${ }^{20}$. Muitas vezes nos seminários e casas de formação, com a desculpa de se formar pastores (para o trabalho pastoral), se descuidou da formação intelectual. Considerava-se o suficiente saber atender o povo e estar engajado com as pessoas, e que o estudo era como que desnecessário/supérfluo. "E continuamos a formar padres de maneira pior que antes do Concílio Vaticano II, pois antes sabiam até grego e latim e hoje sequer português" ${ }^{21}$. Há então, em muitos casos, uma separação entre a formação pastoral e a formação intelectual.

Formar é marcar alguém com uma forma ou fôrma, introduzindo no vocacionado modificações segundo algum paradigma. Na formação sacerdotal, portanto, deve-se oferecer ao seminarista informações, conteúdos e metodologias para que organize sua vida, seus estudos, seus momentos de oração e sua pastoral. Paulo nos apresenta aqueles que Deus estabeleceu na Igreja e que são, em primeiro lugar, os apóstolos; em segundo lugar, os profetas; e em terceiro lugar, os doutores (cf. 1Cor 12,28). Esses três grupos, vê-se claramente, têm a missão do ensino, seja pelo anúncio, como pela denúncia ou por guardarem a fé cristã. Isso se dá de modo perfeito pelo testemunho de suas vidas, mas especialmente pela pregação. Então, quando se fala de Ministério Presbiteral se pensa, também, sobre formação intelectual.

A linguagem expressa sempre uma cosmovisão, e na teologia as imprecisões linguísticas são ruins, porque não acompanham a linguagem do crente. Em geral a formação teológica para atuar nos chamados "novos areópagos e centros de decisão" tem sido insuficiente nas comunidades eclesiais e mesmo nos próprios seminários do Brasil. Grande parte dos seminaristas sofrem as consequências de uma aprendizagem deficiente: "sem hábitos de estudo, leitura e reflexão, com dificuldades para raciocinar, ler e redigir textos, necessitam de ajuda sistemática para cultivar a leitura e a redação, para fazer sínteses e pensar em meio à complexidade do mundo de hoje" (CNBB, Doc. 93, n. 39). Diante dessa mudança de época e frente às exigências da sociedade pós-moderna e urbana, é preciso, então, zelar mais pela qualidade da formação intelectual nos seminários e casas de formação, oferecendo uma formação intelectual séria e profunda, contando com número suficiente de professores bem preparados. Isso tudo para uma maior qualificação e competência dos

20 ZILLES, Urbano. Formação intelectual dos futuros presbíteros, p. 14-15.

21 lbid., p. 7. 
ministros ordenados, futuros teólogos, como serviço a Deus e a seu povo. As Faculdades de Teologia fazem todo um esforço para aproximar a linguagem teológica da linguagem do crente, mas nos seminários o incentivo à formação intelectual nem sempre é satisfatório.

Diante da complexidade dos desafios que se nos apresentam, já devem os seminaristas buscar um nível excelente de formação intelectual, que os ajude a, em primeiro lugar, aprender a pensar, mesmo porque pelo acesso à internet encontramos uma vastidão de informações, mas ela por si não nos faz pensar. Sobre isso a Exortação Pastores Dabo Vobis (n. 56), de João Paulo II, já indicava:

É a própria situação contemporânea a exigir que os mestres estejam cada vez mais à altura da complexidade dos tempos e em condições de afrontar, com competência, clareza e profundidade de argumentação, as carências de sentido dos homens de hoje, às quais apenas o Evangelho de Jesus Cristo dá resposta cabal.

É clara demonstração da finalidade pastoral da formação intelectual dos futuros presbíteros.

Mesmo com essa finalidade pastoral, a vida de estudos apresenta-se também como um desafio. Diante de uma maturidade biológica acelerada, percebe-se certo retardamento no amadurecimento psíquico. Então "uma vida intelectual bem regrada amadurece a personalidade" 22 e pode levar a um prazer que está no fim, embora não sempre no início. Libânio fala da importância do estudo e da dimensão intelectual, como necessidade de uma cultura do estudo, e para nós isso é muito útil, já que muitas vezes essa cultura é vista como aburguesamento ou acomodação, longe de uma ação pastoral encarnada. Declara o autor:

Ao dizer-se cultura do estudo, quer-se dizer hábitos comuns, comportamentos normais, referências consensuais de que estudar, ler, passar horas em casa às voltas com livros não é loucura, raridade ou estranheza de algum caxias exótico, mas deveria ser o normal de alguém que vive no mundo de hoje. ${ }^{23}$

22 LIBANIO, João Batista. Introdução à vida intelectual, p. 29. "O desafio da vida intelectual é saber mostrar que há um prazer que está no fim e não no início. É o prazer intelectual. Implica, porém, um caminho de disciplina, de responsabilidade, de horas e horas de estudo, de tenacidade, de vigílias, de trabalho, de aplicação" (Ibid., p. 32).

23 Ibid., p. 50. 
Para isso não se deve temer exigir hábitos e habilidades no campo intelectual. Grupos de pesquisa, participação em congressos e cursos extracurriculares, interfaces com outras áreas do conhecimento e produção de artigos científicos são alguns exemplos da possível inserção nessa cultura do estudo, fundamental para o diálogo com a ciência e a sociedade.

Se não for levada em conta essa perspectiva, o presbítero pode cometer o erro de deixar-se conduzir pelo ativismo ou pelo fideísmo. São tantas as pastorais e movimentos que requerem sua presença, e muitas vezes não sobra tempo para a atualização intelectual necessária. Ou a oração que não leva em conta a necessidade de se buscar compreender o que se crê. O presbítero é convocado a "estar sempre pronto a dar razão de sua esperança" (cf. 1Pd 3,15). No entanto, o que se vê é que "embora se perceba um crescimento na busca pela formação permanente, ainda é grande o número de presbíteros que agem como se a formação terminasse com a ordenação" "24. Daí a importância, também, da formação permanente interdisciplinar, já recordada por João Paulo II na Exortação Pastores Dabo Vobis (n. 76):

A formação permanente é um dever, antes de mais, para os jovens sacerdotes: deve ter uma tal frequência e sistematização de encontros que, enquanto prolonga a seriedade e a solidez da formação recebida no Seminário, introduza progressivamente os jovens na compreensão e na vivência das singulares riquezas do 'dom'de Deus - o sacerdócio -e na expressão das suas potencialidades e atitudes ministeriais.

Já com relação às instituições para o estudo da Teologia, espera-se que fomentem, de fato, o estudo, a pesquisa e a produção teológica. Nos cursos reconhecidos pelo Ministério da Educação, isso deve ser acompanhado e exigido pelo Estado, mas também a Igreja tem o dever de estar sempre atenta ao ensino teológico, porque

proporcionar um ensino teológico integrado e consistente constitui-se num verdadeiro 'ministério teológico' para diretores, professores, educadores e demais pessoas dedicadas à formação teológica, tendo

24 FERREIRA, Sandro. A vida dos presbíteros no Brasil sob a ótica dos ENPs: desafios e perspectivas, p. 286. "Enquanto em outras áreas do conhecimento se exige sempre mais dedicação e qualidade para obter lugar de trabalho, o emprego do padre está garantido. Se continuarmos nessa linha do minimalismo, amanhã ou depois, formaremos padres à semelhança dos pastores de algumas seitas" (ZILLES, Urbano. Formação intelectual dos futuros presbíteros, p. 8). 
em vista despertar nos futuros presbiteros uma fé iluminada pela razão (CNBB, Doc. 93, n. 171).

Ainda sobre os cursos de filosofia e teologia, experiências demonstram a grande contribuição que existe na dimensão intelectual quando seminaristas participam de Projetos de Iniciação Científica, seja em nível nacional, como estadual ou da própria instituição de ensino. Há como que uma exigência e interesse maiores. Como consequência, se bem aproveitados, uma aprendizagem maior. Sobre a qualificação dos professores, a produção científica é sinal de atualização e seriedade no estudo e ensino, tanto da filosofia quando da teologia. Isso deve ser levado em conta, seja na contratação como na demissão de docentes. Zilles nos ajuda a compreender: "A Filosofia e a Teologia precisam reaprender a dialogar com os opostos, e não só com os clones. Por isso o sacerdote precisa de uma formação filosófico-teológica sólida" ${ }^{25}$.

Poder-se-ia fazer uma pesquisa sobre o perfil dos padres, ou mais especificamente dos teólogos, com índices de satisfação etc., mas também seria muito bom perguntar aos leigos, especialmente aos críticos, se estão satisfeitos com a formação intelectual dos presbíteros, simplesmente a partir das homilias pronunciadas, e também dos teólogos e da linguagem utilizada pelos mesmos, nos seus escritos ou nas suas conferências. Chamado a ser pastor e guia da comunidade paroquial, o presbítero deve ser "mestre da Palavra, ministro dos sacramentos e guia da comunidade". Há uma função social, para fazer a comunidade crescer, em vista do bem comum (cf. 1Cor 12,7). Ele é sempre presbítero e não deve ficar apático ou alienado, ignorante aos sinais e questões dos tempos: "há problemas novos que exigem respostas novas, desafiando, não só a fé, mas também a razão"26. O presbítero e o teólogo são essencialmente seres de relações, seja com o transcendente, seja com a sociedade onde se encontram.

25 Ibid., p. 6. Frei Prudente Nery insiste de que "é preciso que os nossos institutos de filosofia e teologia voltem a ser realmente academias de estudos e pesquisas e não simplesmente escolinhas eclesioprofissionalizantes, lugares apenas de transmissão de amontoado de informações categoricamente ensinadas e timidamente recebidas... é preciso recriar a coragem para o pensar profundo, para a interdisciplinaridade, em que os formandos sejam realmente preparados para o diálogo de nível com os problemas complexos do mundo e das pessoas" (NERY, Prudente. Que eu possa ver de novo! p. 42-43).

26 ZILLES, Urbano. Formação intelectual dos futuros presbiteros, p. 5. 


\section{Considerações finais}

Amedeo Cencini ${ }^{27}$ aponta-nos a importância da ascese e da disciplina em um programa de formação inicial e permanente, se não quisermos pessoas "desmioladas", acostumadas a ter tudo pronto, sempre. E que esta disciplina se torne cada vez mais autodisciplina, e não se reduza à piedosa simulação. Isso se inicia pelo tempo destinado à formação intelectual. Tempo é uma questão de prioridade. Qual a prioridade nos Seminários e Casas de Formação? Como são preparados os teólogos do séc. XXI, destinados a responder aos desafios dos crentes do século XXI? "Somos o que lemos, somos o que escrevemos, somos o que pesquisamos, somos o que ensinamos. Nessa perspectiva, a responsabilidade da vida intelectual recebe nova luz e se torna mais séria e pesada de consequências" 28 .

Isso significa que também no campo da linguagem, mesmo que não tenhamos acesso às experiências dos outros, e mesmo que os teólogos às vezes se prendam às fórmulas, é fundamental essa busca de um nível excelente de formação intelectual, mas que leve em conta também a linguagem do crente, caso contrário o conteúdo teológico se torna "mera emissão de voz".

O teólogo deverá, então, buscar sempre um nível mais alto de formação intelectual, como exigência de seu ofício. Ele não tem mais sua autoridade reconhecida pelo simples fato de pertencer à "classe" sacerdotal ou dos estudiosos das coisas sagradas, mas cada vez mais aquilo que diz sofrerá a crítica racional dos fiéis. E não apenas dos fiéis, porque buscando estabelecer um diálogo com a ciência e a cultura, o teólogo não ficará numa redoma que o imuniza de discordâncias ou contrapontos. Aliás, deverá ele, quanto possível, encontrar e apresentar um raciocínio lógico das verdades da fé, não como um racionalista da fé, mas como alguém que tem razões de sua esperança. Os próprios argumentos de autoridade (auctoritas), seja da Sagrada Escritura ou do Magistério da Igreja, servirão para ele como base e fundamento do raciocínio, mas não como argumentos de convencimento para outrem.

$27 \quad$ CENCINI, Amedeo. A arte de ser discípulo: ascese e disciplina - itinerário de beleza, p. 57. "Ascese e disciplina não significam simplesmente austeridade e rigor, penitência e rostos fechados, mas estão a indicar também, ou acima de tudo, que no caminho de maturação humana e espiritual existem regras e leis que não podem ser negligenciadas, e que quem leva a sério o próprio amadurecimento deve conhecer e respeitar" (Ibid., p. 74).

LIBÂNIO, João Batista. Introdução à vida intelectual, p. 111. 


\section{Referências}

ANSELMO. Proslogion. Tradução de Costa Macedo. Porto: Porto, 1996. CENCINI, Amedeo. A arte de ser discípulo: ascese e disciplina - itinerário de beleza. São Paulo: Paulinas, 2011.

COLLINS, Francis. A Linguagem de Deus. São Paulo: Gente, 2006.

CONFERÊNCIA NACIONAL DOS BISPOS DO BRASIL. Diretrizes para a formação dos presbiteros da Igreja no Brasil. São Paulo: Paulinas, 2010. (Documentos da CNBB 93).

DUQUOC, Christian. A Teologia no Exilio: o desafio da sobrevivência da teologia na cultura contemporânea. Petrópolis: Vozes, 2006.

FERREIRA, Sandro. A vida dos presbíteros no Brasil sob a ótica dos ENPs: desafios e perspectivas. In: REB, vol. 72, fasc. 286, abril 2012.

GIBELLINI, Rosino. A Teologia do Século XX. São Paulo: Loyola, 2012.

HAMMES, Érico João. Pode teologia ser ciência? In: Teocomunicação, Porto Alegre, v. 36, n. 153, set. 2006.

JOÃO PAULO II. Carta encíclica Fides et Ratio: sobre as relações entre fé e razão. São Paulo: Paulus, 1998. . Exortação apostólica Pastores Dabo Vobis sobre a formação dos sacerdotes nas circunstâncias atuais. 8. ed. São Paulo: Paulinas, 2009.

KASPER, Cardeal Walter. Servidores da alegria: existência sacerdotal - serviço sacerdotal. 2. ed. São Paulo: Loyola, 2009.

LIBÂNIO, João Batista. Introdução à vida intelectual. 3. ed. São Paulo: Loyola, 2006.

LIBÂNIO, João Batista; MURAD, Afonso. Introdução à Teologia: Perfil, Enfoques, Tarefas. São Paulo: Loyola, 1996.

NÉDONCELLE, M. Existe uma filosofia cristã? São Paulo: Flamboyant, 1958.

NERY, Prudente. Que eu possa ver de novo! In: CNBB. Metodologia do processo formativo: a formação presbiteral da Igreja no Brasil. 2. ed. São Paulo: Paulus, 2002. 
ROMIO, Jocimar; HACKMANN, Geraldo Luiz Borges. Fé, razão e verdade: a contribuição de Anselmo de Cantuária. In: Teocomunicação. Porto Alegre: EDIPUCRS, v. 38, n. 159, p. 47-63, jan./abr. 2008.

SANCHES, Mário Antonio. O diálogo entre teologia e ciências naturais. O mundo da saúde, ano 31, v. 31, n. 2, abr/jun, 2007. São Paulo: São Camilo, 179-186.

SUSIN, Luiz Carlos. O estatuto epistemológico da teologia como ciência da fé e a sua responsabilidade pública no âmbito das ciências e da sociedade pluralista. In: Teocomunicação. Porto Alegre, v. 36, n. 153, set. 2006.

VASCONCELLOS, M. Fides ratio auctoritas: o esforço dialético no 'Monologion' de Anselmo de Aosta: as relações entre fé, razão e autoridade, Porto Alegre: EDIPUCRS, 2005.

XAVIER, M. L. L. O. O nome anselmiano de Deus, In: A mente, a religião e a ciência: Actas do Colóquio. Centro de Filosofia da Universidade de Lisboa, 2003.

ZILLES, Urbano. História da Teologia Cristã. Porto Alegre: Suliani, 2014.

. Formação intelectual dos futuros presbíteros. Porto Alegre: EDIPUCRS, 2005. 